Г.М. Мендикулова*

Казахи в европейском движении Сопротивления: новые документы из зарубежных архивов

doi:10.31518/2618-9100-2021-3-9

УДК 993.930

Выходные данные для цитирования:

Мендикулова Г.М. Казахи в европейском движении Сопротивления: новые документы из зарубежных архивов // Исторический курьер. 2021. № 3 (17). C. 76-94. URL: http://istkurier.ru/data/2021/ ISTKURIER-2021-3-09.pdf
G.M. Mendikulova*

\section{Kazakhs in the European Resistance Movement: New Documents from Foreign Archives}

\author{
doi:10.31518/2618-9100-2021-3-9
}

How to cite:

Mendikulova G.M. Kazakhs in the European Resistance Movement: New Documents from Foreign Archives // Historical Courier, 2021, No. 3 (17), pp. 76-94. [Available online:] http:// istkurier.ru/data/2021/ISTKURIER-2021-3-09.pdf

Abstract. The article is devoted to the Kazakhs' participation in the European Resistance movement during World War II. It is written based on the documents from the foreign archives, museums and libraries. The author discovered these documents in France, Italy, Norway, Great Britain, Finland, Russia and other countries over the past years, owing to the support from the Presidential Program "People in the Flow of History (2014-2016)" along with grant financing from the Ministry of Education and Science of the Republic of Kazakhstan. For instance, documents found in the French archives describe participation of Kazakhs (who were former Soviet prisoners of war) in liberating such cities as Albi, Carmaux, Toulouse, Montauban, Carcassonne at the end of 1944, both as part of the Maquis and the First Soviet Partisan regiment. New documents made it possible to discover burial spots of ethnic Kazakhs and citizens of Kazakhstan who fought and died in Europe. Moreover, the article tells about research trips to Italy and Russia during which the author discovered facts about several dozens of Kazakhs' participation in the Italian Resistance movement along with details of their repatriation from Italy to the USSR.

Keywords: Kazakhs; Kazakhstanis; World War II; Resistance Movements; Europe; Great Patriotic War; Archives; Documents.

The article has been received by the editor on 14.05.2021.

Full text of the article in Russian and references in English are available below.

Аннотация. Статья посвящена участию казахов в европейском движении Сопротивления в годы Второй мировой войны. Она базируется на документах из зарубежных архивов, музеев и библиотек. Эти документы были выявлены нами во Франции, Италии, Норвегии, Великобритании, Финляндии, России и других странах в последние годы благодаря поддержке Президентской программы «Народ в потоке истории» (2014-2016), а также грантовому финансированию Министерства образования и науки Республики Казахстан. В частности, на основе документов, впервые выявленных во французских архивах, в статье описывается участие казахов из числа бывших советских военнопленных в освобождении таких городов, как Альби, Кармо, Тулуза, Монтобан, Каркасон в конце 1944 г., как в составе отрядов партизан-макизаров, так и Первого советского партизанского полка. Новые документы позволили также обнаружить места захоронений воевавших и погибших в Европе казахов и казахстанцев. Кроме того, в статье рассказывается о поисковых работах, предпринятых в ходе командировок в Италию и Россию, которые позволили выявить факты участия нескольких десятков казахов в итальянском движении Сопротивления, а также подробности их репатриации из Италии в СССР.

\footnotetext{
* Мендикулова Гульнара Малбагаровна, доктор исторических наук, Казахский национальный исследовательский технический университет им. К.И. Сатпаева, Алматы, Казахстан, e-mail: gmendikul@hotmail.com Mendikulova Gulnara Malbagarovna, Doctor of Historical Sciences, Satbayev University, Almaty, Kazakhstan, e-mail: gmendikul@hotmail.com
} 
Ключевые слова: казахи; казахстанцы; Вторая мировая война; движение Сопротивления; Европа; Великая Отечественная война; архивы; документы.

До недавнего времени вопросы участия казахов и казахстанцев в движении Сопротивления в странах Европы были изучены недостаточно. До 1990-х гг. научные исследования базировались в основном на документах, отложившихся в отечественных архивах. Только после распада СССР ученым стали доступны хранилища Западной Европы и США.

Историографию по проблеме установления судеб казахов и казахстанцев, участвовавших во Второй мировой войне, возможно хронологически разделить на две группы: труды, опубликованные в советский период, и исследования, изданные за годы независимости Республики Казахстан. В зарубежной литературе основательных трудов, посвященных участию казахов во Второй мировой войне, нет, т.к. все солдаты назывались советскими (зачастую русскими), а во французских и итальянских источниках и вовсе мы находим определение выходцев из Казахстана, Средней Азии и Кавказа как монголов.

В исследованиях, вышедших в советские годы, отдается предпочтение изучению вопросов участия казахстанцев в борьбе против фашистов в странах Европы, включая участие бывших военнопленных концентрационных лагерей в Сопротивлении. Одним из первых казахстанских историков, посвятивших этой теме диссертационное исследование и ряд статей, был И.И. Маляр ${ }^{1}$. В своей работе автор отмечает, что «сотни воинов казахстанцев принимали участие в движении Сопротивления, причем в некоторых странах (Югославия, Италия, Франция) они составляли небольшие отряды». Массив материалов ему передали бывшие военнопленные, которые участвовали в партизанских отрядах в странах Европы. Согласно И.И. Маляру, в движении Сопротивления в Европе принимали участие 95 казахстанцев в 8 странах: Бельгия - 7 чел., Болгария - 1 чел., Греция - 2 чел., Италия - 28 чел., Польша - 8 чел., Франция - 22 чел., Чехословакия - 13 чел., Югославия - 14 чел. ${ }^{2}$ Эти списки датируются 1967 г., однако они не полные, и сейчас мы стараемся восполнить их в своих поисковых работах.

В приложении к диссертации И.И. Маляр приводит сводные данные по национальности, возрасту и наградам ${ }^{3}$ :

Национальность

казахи - 52 чел.

русские - 41 чел.

остальные - 2 чел.

Возраст (к моменту призыва в армию)

от 17 до 20 лет - 19 чел.

от 20 до 30 лет - 62 чел.

от 30 лет и старше - 14 чел.

Награды (ордена, почетные грамоты)

иностранные награды - 22 чел.

советские награды - 57 чел.

не награждены - 16 чел.

Также к советскому периоду относятся работы М.К. Козыбаева ${ }^{4}$, Г.А. Абишева ${ }^{5}$, П.С. Белана ${ }^{6}$, С. Шакибаева ${ }^{7}$ и др.

Немецкая историография до 1970-х гг. тему советских военнопленных не затрагивала. Подлинным прорывом стала книга К. Штрайта, посвященная пребыванию советских воен-

\footnotetext{
${ }^{1}$ Маляр И.И. Участие казахстанцев в европейском Движении сопротивления // Петров И.И. Всегда начеку. Алма-Ата, 1971. С. 160-168.

${ }^{2}$ Маляр И.И. Участие казахстанцев в антифашистской народно-освободительной борьбе в странах Европы 1942-1945 гг.: дис. ... канд. ист. наук. Алма-Ата, 1968. Прил. 1 (в прил. нумерация страниц отсутствует).

${ }^{3}$ Там же. Прил. 4.

${ }^{4}$ Козыбаев М.К. Казахстан - арсенал фронта. Алма-Ата, 1970.

${ }^{5}$ Абишев Г.А. Казахстан в защите социалистического Отечества. Алма-Ата, 1969.

${ }^{6}$ Белан П.С. Казахстанцы в боях за Ленинград. Алма-Ата, 1973.

${ }^{7}$ Шакибаев С. Падение «Большого Туркестана». Алма-Ата, 1973.
} 
нопленных в германском плену․ В 1981 г. вышел труд немецкого исследователя А. Штрайма об отношении к советским военнопленным в операции «Барбаросса» 9 .

До 1990-х гг. были исследованы проблемы участия советских людей в партизанском и Национально-освободительном движении в Югославии. Как известно, в Югославии существовала огромная система концлагерей, из которых заключенные массово уходили к партизанам. Примерно 900 чел. бежали из мест лишения свободы, находившихся в Италии и Австрии, а на пути в Народно-освободительную армию Югославии воевали в гарибальдийских формированиях, в которых были представители 30 национальностей СССР, в т.ч. казахи ${ }^{10}$.

Ергалиев Рамазан (псевдоним Алексей), казах, сержант, погиб 14 марта 1944 г., прикрывая отход партизан Бришско-Бенечского отряда. За свой героизм посмертно награжден орденом «За храбрость». Раисов Бейсен Акимович (псевдоним Борис), казах, сержант. В августе 1942 г., раненый, попал в плен под Калачом. В октябре 1943 г. бежал из 162-й пехотной дивизии вместе с Сабитом Кулямировым к итальянским партизанам. Узнав о советских людях среди словенских партизан, оба перешли в Бришско-Бенечский отряд, в ноябре 1943 г. были переведены в «русскую» роту 18-й Словенской бригады. Б.А. Раисов был дважды ранен и один раз контужен. В числе первых бойцов 18-й Словенской бригады получил орден «За храбрость» ${ }^{11}$.

Сабит Кулямиров (партизанский псевдоним Сергей), 1914 г.р., казах, мл. политрук, первый комиссар 2-го «русского» батальона 18-й Словенской Базовицкой бригады. Погиб 19.02.1944 г. в бою с эсэсовцами у с. Край ${ }^{12}$.

Разрозненные данные подтверждают тот факт, что в Балканских странах комплексные исследования не проводились, хотя в 2018 г. наши дипломаты Р. Василенко и К. Сарыбай обнаружили в Словении захоронение Кассе Себеро - солдата из Казахстана по имени (предположительно) Касым Жакупов ${ }^{13}$.

Российскими историками были изучены вопросы жизни советских военнопленных в нацистских лагерях, репатриация, коллаборационизм, численность советских военнопленных, условия содержания пленных в концентрационных лагерях на территории Германии, Австрии, Польши, Франции, Норвегии. Это труды таких ученых, как И.А. Дугас, Ф.Я. Черон ${ }^{14}$, Ж. Котек, П. Ригуло ${ }^{15}$, П.М. Полян ${ }^{16}$, В.Н. Земсков ${ }^{17}$, М.И. Семиряга ${ }^{18}$, М.М. Паникар ${ }^{19}$ и др.

Обратную сторону содержания иностранных военнопленных в лагерях СССР в своей монографии, посвященной истории пребывания иностранных военнопленных и интернированных в Сибири в 1943-1950 гг. ${ }^{20}$, воссоздают А.А. Долголюк и Н.М. Маркдорф. В лагеря

\footnotetext{
${ }^{8}$ Streit Ch. Keine Kameraden: Die Wehrmacht und die sowjetischen Kriegsgefangenen, 1941-1945. Bonn, 1997.

${ }^{9}$ Streim A. Die Behandlung sowijetischer Kriegsgefangenenlager im “Fall Barbarossa”. Heidelberg; Karlsruhe, 1981.

${ }^{10}$ Советские люди в освободительной борьбе югославского народа: 1941-1945 гг. Воспоминания, документы и материалы. М., 1973.

${ }^{11}$ Там же. С. 42.

${ }^{12}$ Казак В.Н. Побратимы. Советские люди в антифашистской борьбе народов балканских стран 1941-1945. М., 1975. С. 15.

${ }^{13}$ Смайыл М. Кассе Себеро - стало известно настоящее имя героя-казаха. 01.10.2018 // Tengrinews [Электронный ресурс]. URL: https://tengrinews.kz/story/kasse-sebero-stalo-izvestno-nastoyaschee-imya-geroya-kazaha354674/ (дата обращения: 24.03.21).

${ }^{14}$ Дугас И.А., Черон Ф.Я. Вычеркнутые из памяти. Советские военнопленные между Гитлером и Сталиным. Париж, 1994.

${ }^{15}$ Котек Ж., Ригуло П. Век лагерей. Лишение свободы, концентрация, уничтожение. Сто лет злодеяний. M., 2003.

${ }^{16}$ Полян П.М. Жертвы двух диктатур: жизнь, унижения и смерть советских военнопленных и остарбайтеров на чужбине и на родине. М., 2002.

${ }^{17}$ Земсков В.Н. Возвращение советских перемещенных лиц в СССР. 1944-1952 гг. М., 2016.

${ }^{18}$ Семиряга М.И. Коллаборационизм. Природа, типология и проявления в годы Второй мировой войны. M., 2000.

${ }^{19}$ Паникар М.M. Советские военнопленные в Норвегии в годы Второй мировой войны. Архангельск, 2010.
} 
после репатриации попадали и советские военнопленные, уже у себя на Родине, куда они так стремились вернуться и за которую сражались на чужбине.

Норвежский историк М.Н. Солейм ${ }^{21}$ пишет о положении советских военнопленных в Норвегии в годы войны. Работа базируется на документах из архивохранилищ Норвегии, Германии, Великобритании, на воспоминаниях бывших военнопленных, свидетельствах очевидцев.

После обретения суверенитета в казахстанской исторической науке произошли крупные перемены, связанные с отходом от коммунистической идеологии и становлением нового исторического сознания. В эти годы были опубликованы труды Г.М. Мендикуловой ${ }^{22}$, Б.Г. Аягана ${ }^{23}$, Б.И. Садыковой ${ }^{24}$, А. Кара ${ }^{25}$, А. Кәкена ${ }^{26}$, С. Бекенова ${ }^{27}$ и других исследователей, посвященные историческим судьбам казахской диаспоры, туркестанским легионерам, военному плену, жизни в эмиграции и, конечно же, участию казахстанцев в движении Сопротивления в странах порабощенной Европы. Вышеуказанные исследования определили новый подход в изучении участия казахов в войне.

В последние годы, благодаря научным изысканиям нашей исследовательской группы при поддержке Президентской программы «Народ в потоке истории» (2014-2016 гг.), а также гранту Министерства образования и науки РК ГФ2018/АР05130249 «Казахи во Второй мировой войне: новые документы из зарубежных архивов» (2018-2020 гг.), были обнаружены новые документы в архивах стран Европы.

Исполнителями этих фундаментальных проектов были опубликованы статьи в Казахстане, России, Монголии и Украине ${ }^{28}$, в которых дана краткая информация об архивах. За годы НИР были собраны и опубликованы документы из 18 зарубежных архивов, музеев и библиотек Франции, Италии, Норвегии, Великобритании, Финляндии, России и др., а именно: UK National Archives, Национальный архив Норвегии (Riksarkivet), Archives nationales à Pierrefitte-sur-Seine, Musée de la Résistance Nationale à Champigny-sur-Marne,

${ }^{20}$ Долголюк А.А., Маркдорф Н.М. Иностранные военнопленные и интернированные в Сибири (1943-1950). M., 2016.

${ }^{21}$ Soleim M.N. Sovjetiske Krigsfanger i Norge 1941-1945; Antall, Organisering og repatriering. Oslo, 2009.

${ }^{22}$ Мендикулова Г.М. Исторические судьбы казахской диаспоры. Происхождение и развитие. Алматы, 1997.

${ }^{23}$ Аяган Б.Г. Красные и черные (материалы Гуверовского архива). Алматы, 2005.

${ }^{24}$ Садыкова Б.И. История Туркестанского легиона в документах. Алматы, 2002.

${ }^{25}$ Қара А. Түркістан легионның ақиқаты: свастика мен қызыл жұлдыз арасындағы жанталас. Түркістан, 2011.

${ }^{26}$ Кәкен А. Түркістан легионы. Астана, 2000.

${ }^{27}$ Бекенов С. Қазақ тұтқыны. Алматы, 2007.

${ }^{28}$ Мендикулова Г.М., Надежук Е.А., Габдуллина А.Ж., Акатаева А.А, Тумабаев Т.С. Военнопленные казахи в лагерях Норвегии и Финляндии в годы Второй мировой войны // Вопросы истории. 2019. № 10. С. 169-178; Мендикулова Г.М. О компаративистике и достоверности архивных и оцифрованных документов об участии казахов во Второй мировой войне // Социо-гуманитарные науки в цифровом мире: сб. мат-лов Междунар. кругл. стола. Алматы, 2018. С. 19-23; Mendikulova G.M. New documents about Kazakhs (called Mongols) in France in 1944-1945 // Евразийская цивилизация: история и современность: сб. мат-лов Междунар. науч.-практ. конф. Улаанбаатар, 2018. С. 69-72; Mendikulova G.M., Nadezhuk E.A. The Participation of Kazakhs in the Resistance Movement in France and Italy during the World War II: Problem Posing // Вестник КазНУ. Сер.: Историческая. 2018. № 3 (90). С. 9-15; Габдуллина А.Ж. «В тени памяти» или судьба бывшего военнопленного Мажита Бектанова // Социо-гуманитарные науки в цифровом мире: сб. мат-лов Междунар. кругл. стола. Алматы, 2018. С. 33-35; Мендикулова Г.М. Памятники казахским воинам на французской земле // Сб. мат-лов междунар. науч.-практ. конф. «Батыры Великой степи», 19.10.2018, Астана, 2018. С. 174-179; Філінюк А., Мендікулова Г., Клімчук Ю. Участь представників України та Казахстану у французькому русі опору періоду Другої світової війни: транснаціональний аспект // Вісник Кам’янець-Подільського національного університету імені Івана Огієнка. Історичні науки. 2018. Вип. 11. С. 532-550; Mendikulova G., Nadezhuk E., Akatayeva A. New Documents on Kazakhs in the European Resistance Movements during World War II // Journal of Modern Turkish History. Spring 2019. Vol. 15. Iss. 29. P. 205-226; Mendikulova G., Nadezhuk E. Kazakh-Russian roots of Alla Ilchun (Yelshin), Combated with fascism, the future Muse of Christian Dior (December 10, 1926 - March 6, 1989) // Вестник КазНУ им. Аль-Фараби. Сер. историческая. Окт. 2019. № 3 (94). С. 101-107; Мендикулова Г.М., Надежук Е.А., Акатаева А.А., Оспанов T.T., Тумабаев T.С. Участие казахов в Движении Сопротивления в Бельгии (новые архивные документы) // Вестник КарГУ. 2020. № 3. С. 172-182. 
Centre des Archives diplomatiques, Archive de la Préfecture de Police de Paris, Bibliothéque Institute National des Lanques et Civilisations Orientales, Service Historique de la Défense, Archives Départamentales du Tarn, Archives Départamentales Haute-Garonne, Musée départemental de la Résistance (Франция), Istituto storico della Resistenza in Toscana, Istituto Storico Parri Emilia Romagna (Италия), ГА РФ, РГАСПИ, Архив Дома русского зарубежья им. А. Солженицына (Россия), Национальный архив Финляндии (Kansallisarkisto), норвежская база данных «Военные могилы иностранцев в Норвегии» (Krigsgraver) и др. В них найдены новые документы об участии казахов в движении Сопротивления этих стран, обнаружены захоронения воевавших и погибших там казахов и казахстанцев ${ }^{29}$.

В 2018 г. в Алматы опубликован первый том сборника документов «Казахи во Второй мировой войне: документы из зарубежных архивов» ${ }^{30}$, презентации которого были проведены в Алматы (Казахстан), Питтсбурге (США) и Париже (Франция). Третьего мая 2019 г. в Посольстве РК во Франции состоялась презентация сборника документов, которая освещалась в СМИ ${ }^{31}$ В 2020 г. опубликован второй том сборника документов ${ }^{32}$. Его презентация намечена на 2021 г.

Необходимо остановиться на документах, повествующих о деятельности казахстанцев, оказавшихся во Франции и Италии. В декабре 1943 г. по инициативе ЦК французской компартии был создан Центральный Комитет Советских военнопленных во Франции ${ }^{33}$, который действовал до декабря 1944 г. Он объединял более 20 региональных комитетов в различных лагерях, главным образом на западе, востоке и севере страны, частично в Бельгии. В состав комитета входили М. Слободзинский, В. Таскин, Н. Скрипай, В. Порик, Н. Смарчевский, А. Кочетков, Сикочинский, И. Троян, П. Лисицин, Г. Шибанов.

Комитет занимался организацией побегов пленных, а также созданием советских партизанских отрядов, крупнейший из которых носил имя Сталина и действовал в департаменте Паде-Кале. На востоке Франции действовали советские партизанские отряды: «Сталинград» ${ }^{34}$ (командир Георгий Пономарев), «Щорс» (Дмитрий Рудковский), «Чапаев» (Василий Турецков), «Ковпак» (Федор Богачев), «Парижская коммуна» (Валерий Соломатин), «За Родину» (Николай Зайцев), «Донбасс» (Павел Чавчишвили), «Котовский» (Иван Третьяков), «Котовский» (Вениамин Ситников), «Родина» (Иван Максимов), «Свобода» (Иван Самарин), «За Свободу» (Алексей Смолкин), «Катерина» (Владимир Шабунин), «Железняк» (Андрей Цибиков), женская группа «Родина» (Розалия Фирдзон, псевдоним Симонова), «Жуков» (Алексей Сидоров), «Полтава» (Филатов), «Севастополь» (Николай Серебряков), «Смерть фашизму» (Федор Лиховец) $)^{35}$.

\footnotetext{
${ }^{29}$ Мендикулова Г.М. В зарубежных архивах нашли информацию о казахстанцах, участвовавших в ВОВ. 06.05.2019 // Телеканал «Хабар 24». URL: https://24.kz/ru/news/social/item/313207-v-zarubezhnykh-arkhivakhnashli-informatsiyu-o-kazakhstantsakh-uchastvovavshikh-v-vov (дата обращения: 24.03.21). Мендикулова Г.М. Интервью радиоточке «Малоизвестные страницы истории войны» - «Культпросвет». 06.05.2015; Мендикулова Г.М. Соғыс туралы шындық өлі айтылып біткен жоқ // Алматы акшамы. 10.02.2015, б. 6-7; Канафина Ж. Туркестанцы во Второй мировой войне: из плена в Сопротивление. 13.05.2016 // Informburo. URL: http:// informburo.kz/stati/turkestancy-vo-vtoroy-mirovoy-voyne-iz-plena-v-soprotivlenie.html (дата обращения: 24.03.21). Мендикулова Г.М. Казахские партизаны во Франции: как казахи воевали в Европейском движении Сопротивления. 16.06.2016 // Vox Populi. URL: http://www.voxpopuli.kz/history/kazahskie-partizany-vo-francii-kak-kazahivoevali (дата обращения: 24.03.21); Мендикулова Г.М. Вторая мировая война: сражения отгремели, проблемы остались. 01.09.2016 // Интернет-газета Zona.kz. URL: https://zonakz.net/2016/09/01/vtoraja-mirovaja-vojjnasrazhenija-otgremeli-problemy-ostalis/ (дата обращения: 24.03.21).

${ }^{30}$ Казахи во Второй мировой войне: документы из зарубежных архивов.: сб. док-тов. Алматы, 2018. Т. 1.

${ }^{31}$ Сыздыкова А., Тепсаев Б. В зарубежных архивах нашли информацию о казахстанцах, участвовавших в ВОВ. 06.05.2019 // Телеканал «Хабар 24». URL: https://24.kz/ru/news/social/item/313207-v-zarubezhnykh-arkhivakhnashli-informatsiyu-o-kazakhstantsakh-uchastvovavshikh-v-vov (дата обращения: 18.03.2021).

${ }^{32}$ Казахи во Второй мировой войне: документы из зарубежных архивов: сб. док-тов. Алматы, 2020. Т. 2.

${ }^{33}$ Доклад ЦК Компартии Франции о состоянии работы среди советских пленных во Франции. РГАСПИ. Ф. 553. Оп. 1. Ед. хр. 1. Л. 1-6об.

${ }^{34}$ Несколько групп «Сталинград» действовало на территории 4 регионов Франции, в которых воевали советские воины. Одну такую группу «Сталинград» возглавили казахи Кадем Жуманиязов и Зунум Джаманкулов.

${ }^{35}$ В скобках даны фамилии руководителей партизанских отрядов.
} 
ЦКСП направлял работу партизанских отрядов, готовил побеги военнопленных, издавал листовки и воззвания среди советских граждан, в которых был призыв бороться с врагами путем организации саботажей, диверсий на шахтах и предприятиях.

В июле 1944 г. из лагеря Альби был совершен массовый побег бывших военнопленных. Вскоре из советских пленных было создано отдельное формирование. Позднее к ним присоединились бывшие узники освобожденных лагерей Дебернет и Кастр, после чего был сформирован Первый советский партизанский полк, командиром которого стал грузин, лейтенант Отари Ишхнели, начальником штаба - казах Али Молдагалиев, комиссаром - серб, батальонный комиссар Ивич, старшим врачом - Ахмет Бектаев. В составе полка насчитывалось около 300 казахстанцев: Утеуле Бисенгалиев (замкомандира батальона), С. Жумашев (Атырау), Канысбаев, Н. Кунаев (Саратовская область), западноказахстанцы Ж. Катшиков, С. Каренов, Д. Каражумин, Н. Утешев, Б. Едрисов, 3. Амангалиев, Ш. Балыков, семипалатинцы Н. Ильясов, М. Нугманов, Г.М. Мартыненко, К. Хангереев, Б. Сексенбаев из ТалдыКургана, Шамиль Хасанович Хусаинов (Северо-Казахстанская область) и др.

В 1944 г. в стране действовало около 50 советских партизанских отрядов. Бывшие легионеры и военнопленные из Казахстана воевали в составе таких отрядов, как «Сталинград» и «Монголы». Их бойцы нападали на небольшие немецкие гарнизоны, подрывали железнодорожные составы, освобождали пленных. В конце этого же года они уже участвовали в освобождении французских городов, в т.ч. Альби, Кармо, Тулузы, Монтобана, Каркасона. Среди командиров отрядов своим героизмом отличились казахи Зунум Жаманкулов и Кадем Жуманиязов.

Документы, удостоверяющие участие казахов в освобождении Франции, были собраны из Archives Départamentales Haute-Garonne, Musée départemental de la Résistance, Archives Départamentales du Tarn, Archives Nationales and Service Historique de la Défense, Росийской государственной библиотеки и Архива Дома русского зарубежья им. А. Солженицына. Так, мы располагаем документами, обнаруженными в Archives Départamentales du Tarn, в частности рапортом об освобождении г. Кармо ${ }^{36}$, в котором сказано, что после работ по дезорганизации легионов, расположенных в г. Кармо, уже несколько месяцев спустя немецкие офицеры, не совсем уверенные в этих самых легионах, в конце концов оставили в Кармо только те части, которые изначально были действительно нацистскими.

В другом деле обнаружена карта освобождения г. Тарн, на которой четко видны действия и расположение групп «Сталинград» и «Монголы» ${ }^{37}$ (рис. 1).

Еще одна карта была найдена в Архиве Министерства обороны Франции. На ней также показаны действия макизар, групп «Сталинград» и «Монголы» в деле освобождения юга Франции, в частности г. Тарн ${ }^{38}$ (рис. 2).

Немало информации о Первом советском полке можно найти в интернете, однако никаких данных об участии в нем казахов и казахстанцев практически не приводится.

Наша исследовательская группа обнаружила и получила от родственников участников тех событий копии документов, удостоверяющих их участие в боевых действиях Первого советского партизанского полка. Так, Кайрош Ногаев - внук лейтенанта Абу Имаевича Молдагалиева, прислал нам фотографию удостоверения о том, что уже капитан Абу Молдагалиев ${ }^{39}$ участвовал в борьбе за освобождение юга Франции в Первом советском партизанском полку. Абу Имаевич, 1922 г.р. из Караганды, доблестно воевал с фашистами во Франции, вернулся в Караганду, где работал учителем ${ }^{40}$ (рис. 3).

\footnotetext{
${ }^{36}$ Archives Départamentales du Tarn. 348 W 86. Рапорт об освобождении г. Кармо. Р. 2-5. В публикуемом документе сохранены авторская пунктуация и стилистика.

${ }^{37}$ Archives Départamentales du Tarn. MS 691. La Liberation de Tarn. Карта освобождения г. Тарн.

${ }^{38}$ Service Historique de la Défense. GR 19P FFI 5RM TARN As B9 Maquis Stalingrad. Карта военных действий при освобождении Департамента Тарн.

${ }^{39}$ В документе указана другая дата рождения - 02.12.1917 г.

${ }^{40}$ Казахи во Второй мировой войне... Т. 1. С. 124.
} 


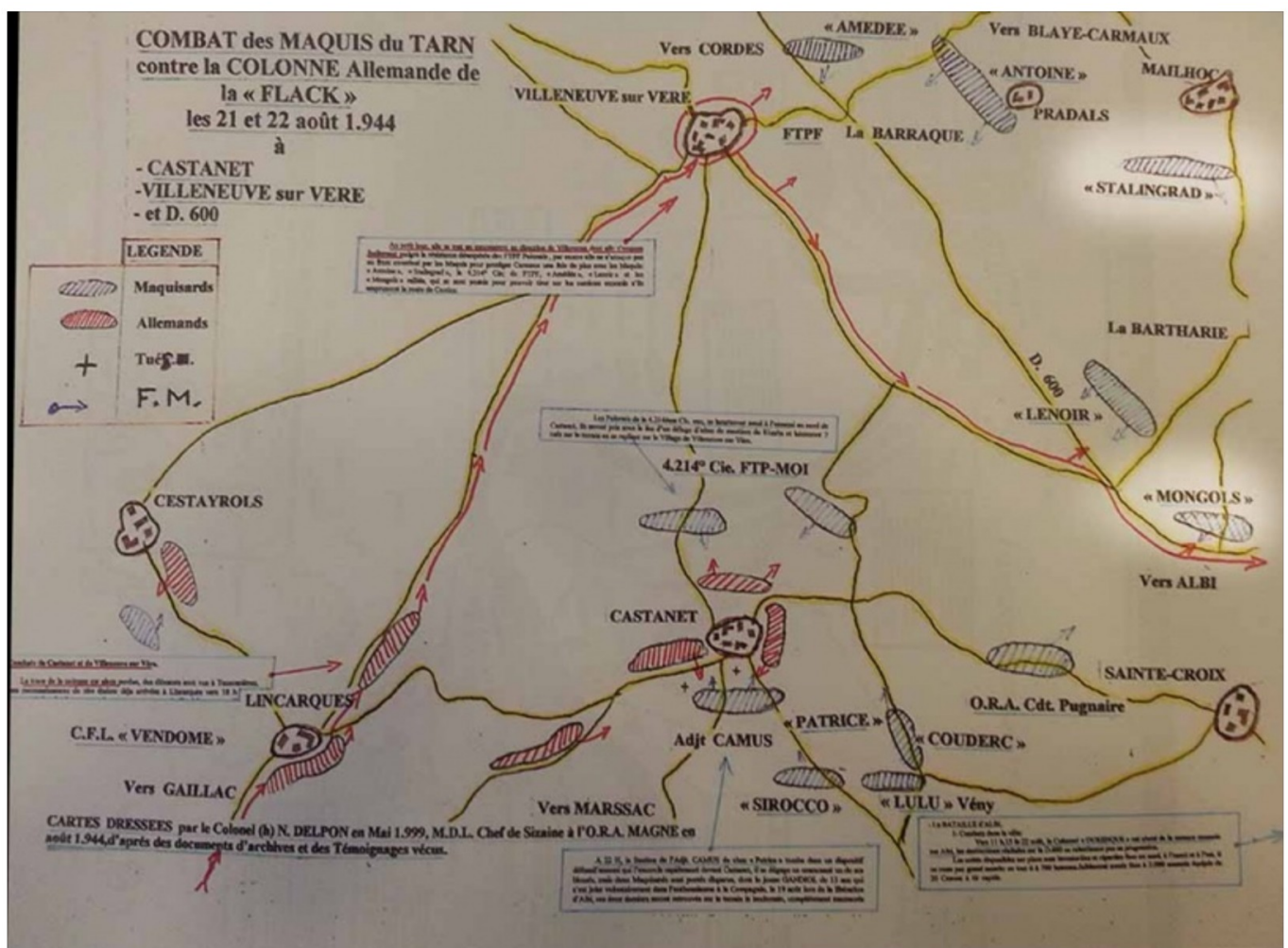

Рис. 1. Карта освобождения г. Тарн.

Archives Départamentales du Tarn. MS 691. La Liberation de Tarn.

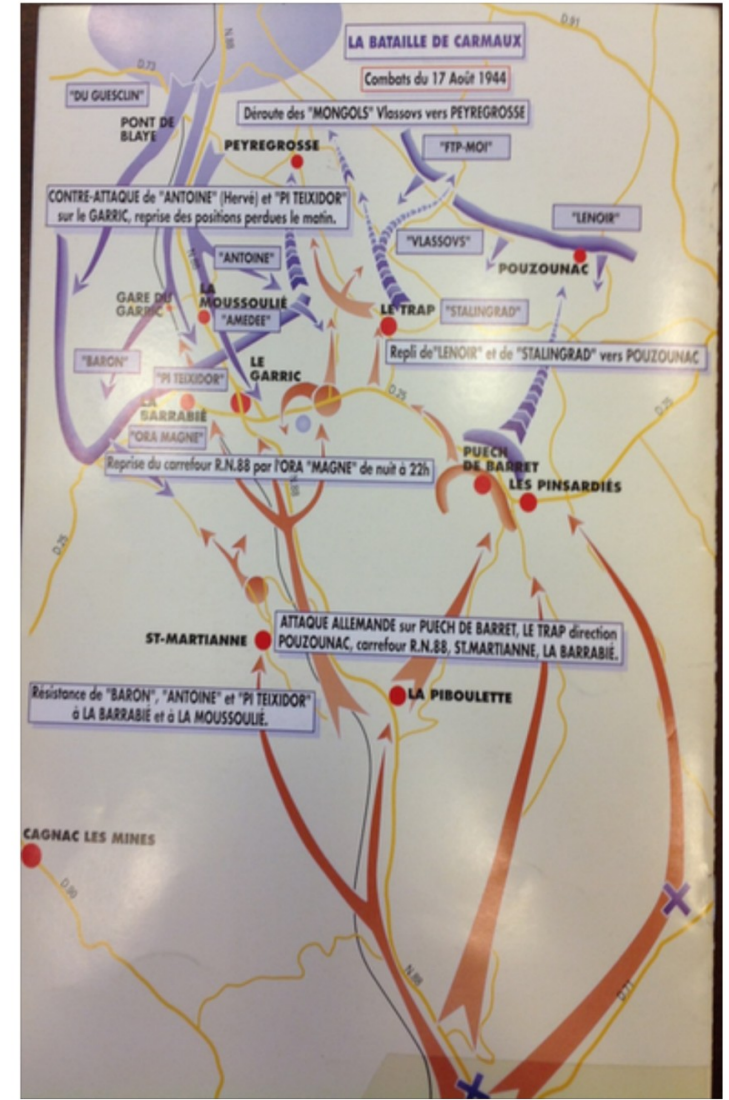

Puc. 2. Карта военных действий при освобождении Департамента г. Тарн.

Service Historique de la Défense. GR 19P FFI 5RM TARN As B9 Maquis Stalingrad.

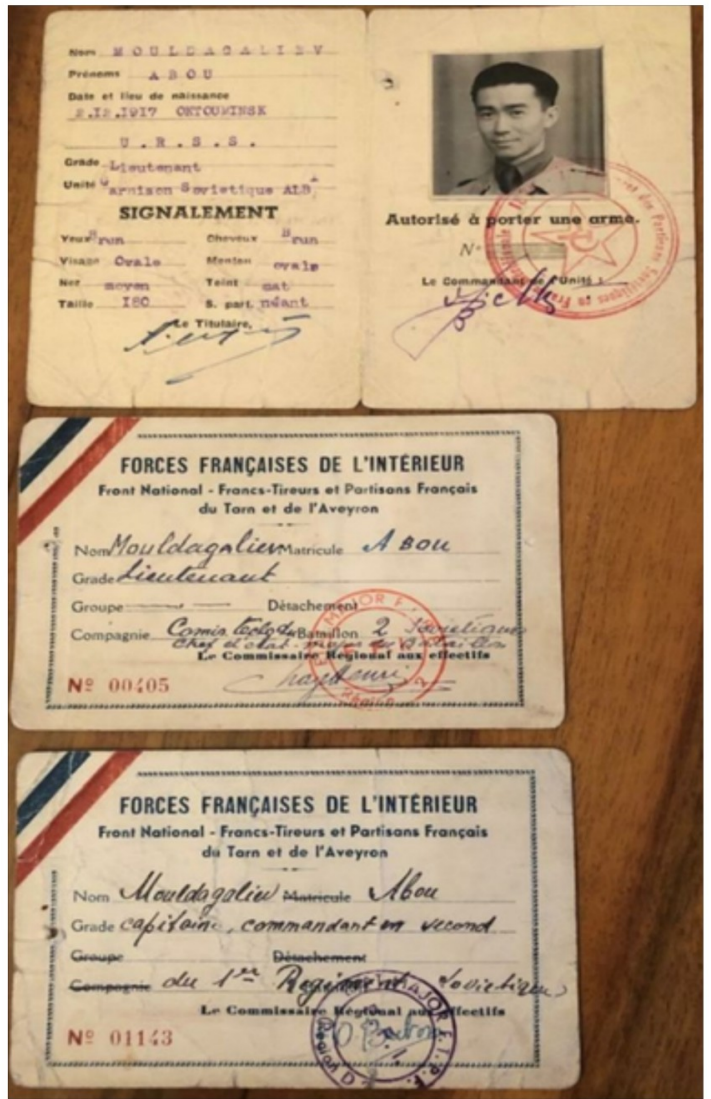

Puc. 3. Копия удостоверения капитана Абу Молдагалиева, участвовавшего в борьбе за освобождение юга Франции в Первом советском партизанском полку. 
Сын Шашубая Бейсембина Мурата предоставил нам сведения о своем отце Шашубае, 1920 г.р., уроженце аула № 7 Карагандинской области, (совхоз им. Кирова Майского района Павлодарской области), который был призван в ряды Красной (Советской) армии в декабре 1940 г. в г. Пушкино Ленинградской области (согласно записей: 24-й танковый корпус, 8-й моторизированный полк). Когда началась война, 18 августа 1941 г., находясь в окружении в районе с. Каменка Ленинградской области, попал в плен и находился в концентрационных лагерях Латвии, Польши и Франции. Осенью 1943 г. бежал из плена в районе г. Альби (Франция) и присоединился к французским партизанам (рис. 4).

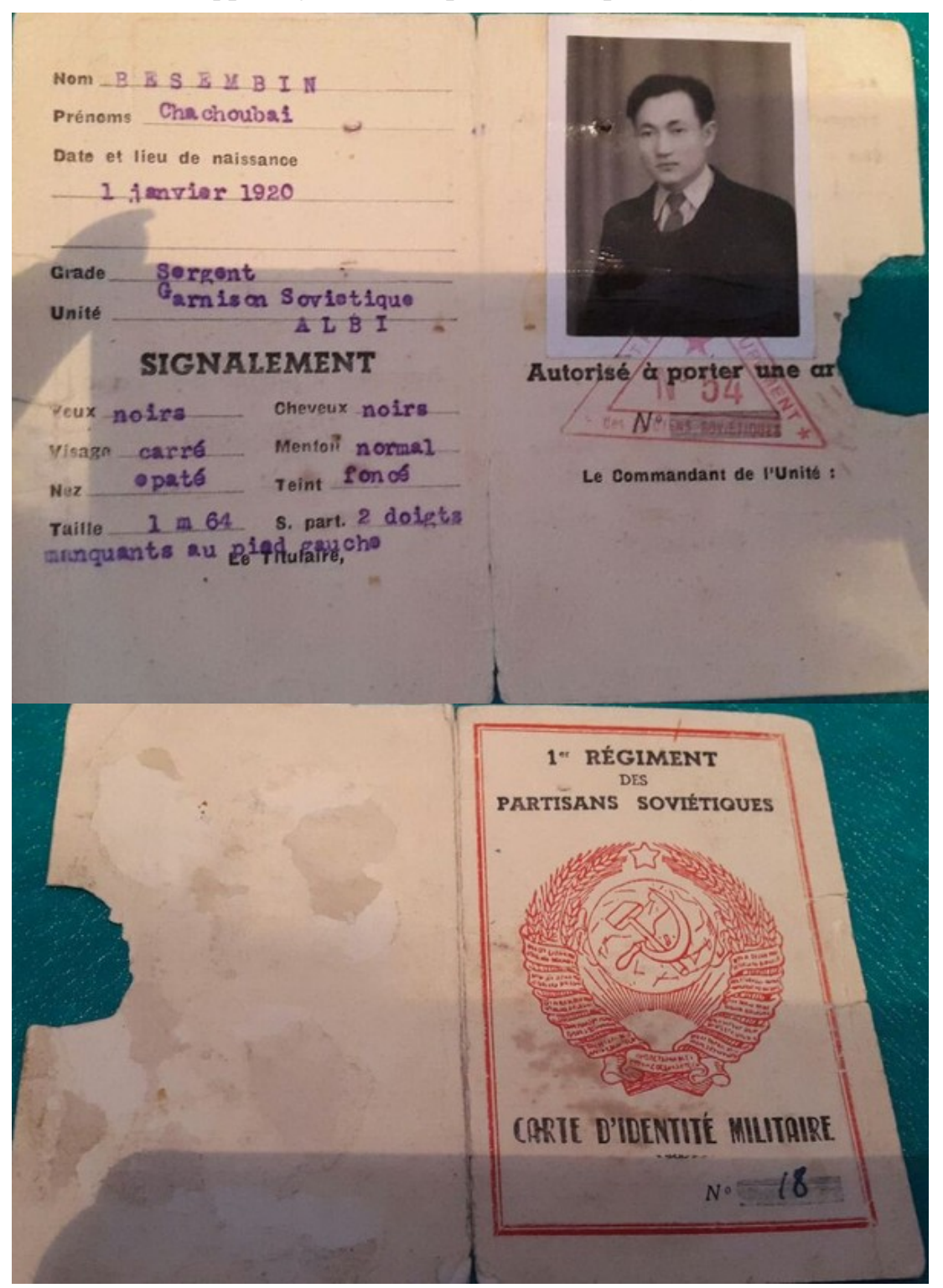

Puc. 4. Копия удостоверения сержанта Шашубая Бейсембина, участвовавшего в борьбе за освобождение юга Франции в Первом советском партизанском полку.

После победы над гитлеровской Германией в декабре 1945 г. вернулся домой, в 1946 г. был арестован и осужден по ст. 58-10 УК РСФСР на 10 лет, скончался в декабре 1996 г. (после операции сказались ранения). Реабилитирован в октябре 1999 г.

Койшибаев Абибулла Койшибаевич, казах, родился 15.05.1920 г. в г. Джамбуле Джамбулской области Казахской ССР. В 1939 г. окончил Джамбулское педагогическое училище, до призыва в армию работал учителем начальных классов. 02.10.1940 г. был призван в армию Джамбулским ГВК. Когда началась Великая Отечественная война, он служил в 638-м стрелковом полку, 115-й стрелковой дивизии Ленинградского фронта, участвовал в прорыве блокады на плацдарме «Невский пятачок» близ с. Невская Дубровка. 
При возвращении из разведки в тылу врага он подорвался на мине, был оглушен и тяжело ранен, попал в плен 10.12.1941 г. Содержался в лагере для военнопленных в г. Луга, после чего был переправлен в Германию, потом во Францию. Находясь во Франции в августе 1944 г., бежал из лагеря для военнопленных, присоединился к французским партизанам. Оттуда попал в Первый советский партизанский полк, в составе которого принимал участие в освобождении Франции, был командиром взвода комендантской роты (рис. 5).

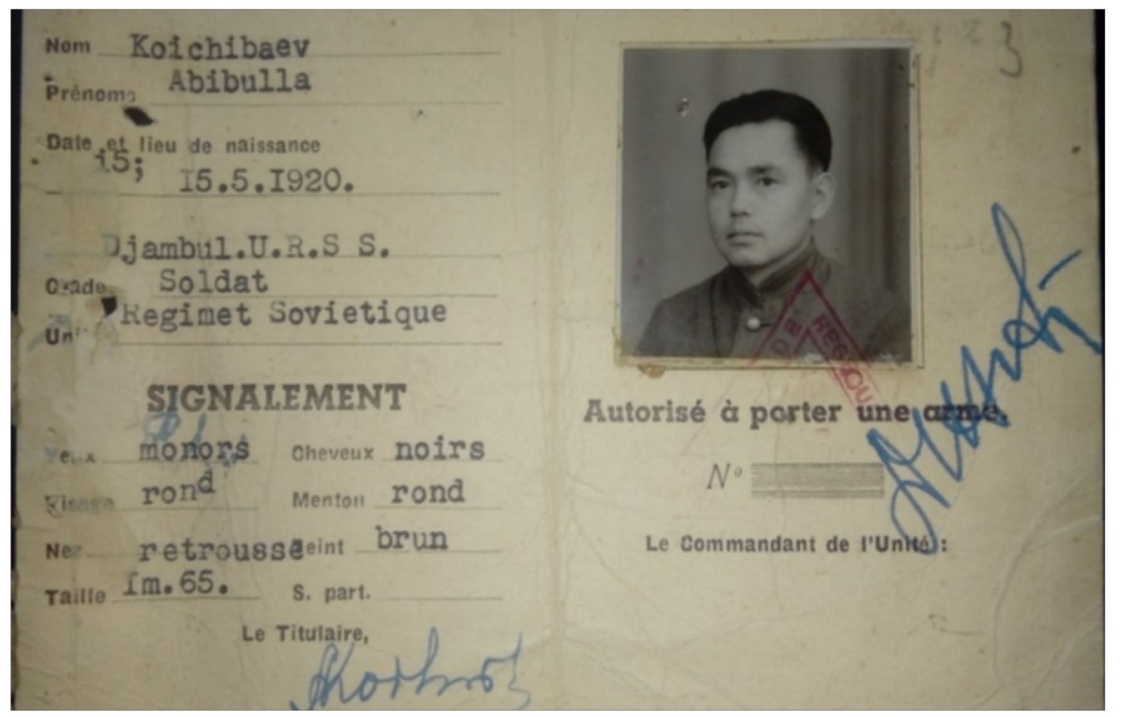

Puc. 5. Копия удостоверения солдата Абибуллы Койшибаева, участвовавшего в борьбе за освобождение юга Франции в Первом советском партизанском полку.

Шестого сентября 1945 г. эшелоном в составе 1-го советского партизанского полка прибыл в Тульскую область, оттуда прошел через фильтрационный лагерь НКВД. В 1946 г. прибыл домой, где через два дня был арестован и осужден Туркестанским военным трибуналом к 10 годам лишения свободы с поражением в политических правах. 27.10.1955 г. был освобожден со снятием судимости. Но работать учителем в школе не разрешили из-за судимости. Он окончил Джамбулский зооветеринарный техникум. Некоторое время работал зооветеринаром. Затем долго работал заместителем директора Культпросветучилища по хозяйственной части. На его здоровье сказались война, немецкие концлагеря, сталинские лагеря, где он пробыл 15 лет. Умер 19.02.1976 г.

В СМИ в 2005 г. была опубликована следующая информация: «Только во II полку было 300 казахстанцев, замкомандира полка был Абу Молдагалиев, командиром 8-й роты Утеули Бисенгалиев, потом ставший замкомандира батальона, Кабыш Омаров - командир партизанского отряда. Все они бывшие кадровые военные» (рис. 6).

B Musée départemental de la Resistance (Toulouse) в выставочном зале было обнаружено фото Парада освобождения Тулузы от немецко-фашистских захватчиков 16 сентября 1944 г. Известно, что в это время казахи в числе отрядов Первого советского партизанского полка прошли по площади на параде в честь освобождения Тулузы. На трибунах присутствовал Шарль Де Голль, который заметил казахов из-за их необычной внешности ${ }^{41}$ (рис. 7).

Освобожденные советские пленные оставались во Франции до осени 1945 г. Местное население относилось к ним пренебрежительно. Солдаты Красной армии, боровшиеся в рядах Сопротивления, после освобождения оставались проживать в немецких лагерях (рис. 8). О факте презрительного отношения к освободителям свидетельствует инцидент, произошедший с участием граждан Советского Союза. В мае 1945 г. наши соотечественники подрались в кафе с местными жителями ${ }^{42}$. Участники столкновения попали в полицию.

\footnotetext{
${ }^{41}$ Bertaux P. La libération de Toulouse et de sa région - Haute-Garonne, Ariège, Gers, Hautes-Pyrénées, Lot, Lot-etGaronne, Tarn, Tarn-et-Garonne. Paris, 1973. P. 93. (La Libération de la France).

${ }^{42}$ Archives Départamentales du Tarn. MS 691. La Liberation de Tarn. P. 2-4, 332-340, 445, дальше документы не пронумерованы.
} 
Поводом послужили оскорбления со стороны французов. Согласно документам, такие потасовки не были единичными.

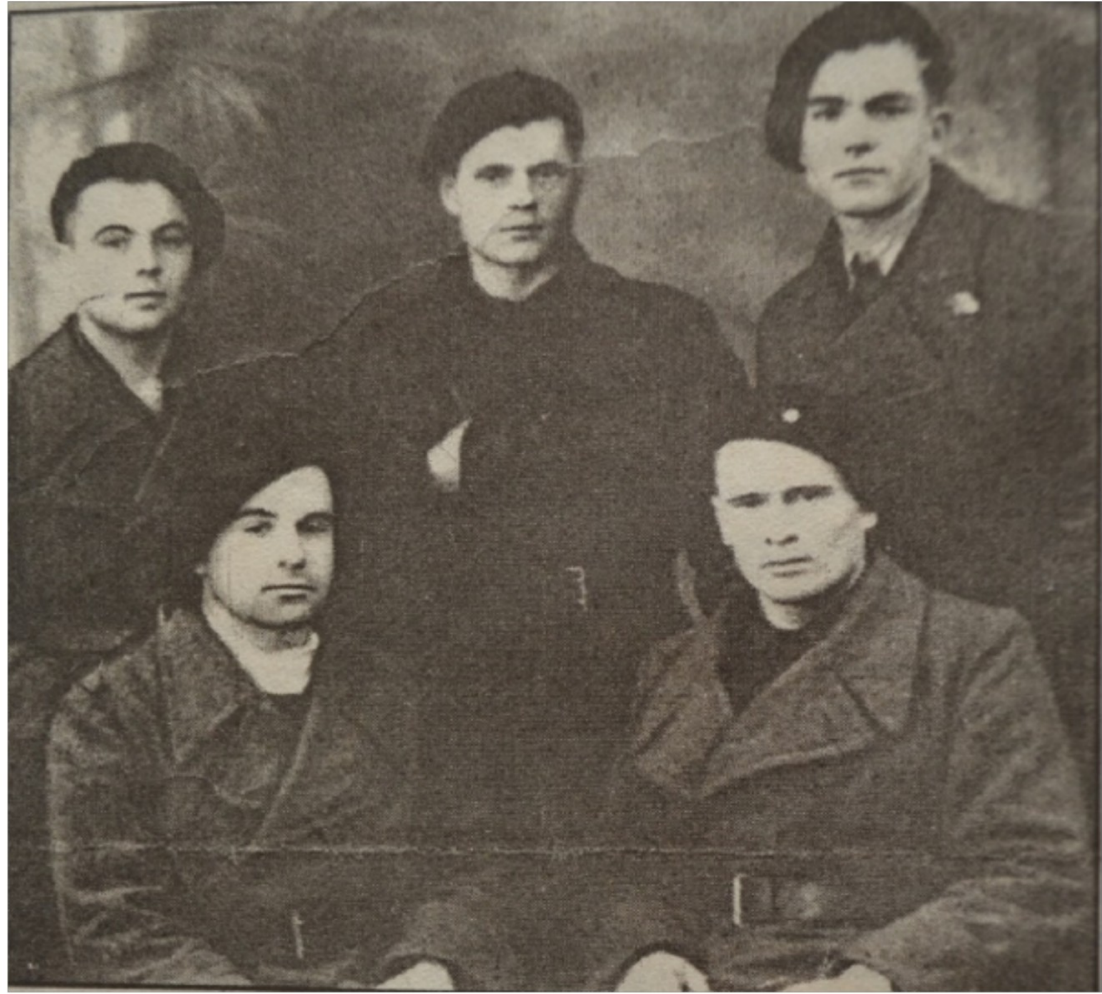

Puc. 6. Группа советских участников французского Сопротивления роты вольных стрелков. Сидят (слева направо): Герольд Люстерник (Выборг),

Михаил Медведев (Курск). Стоят: Иван Пономаренко (Сумщина), Алексей Насулин (Казахстан), Владимир Бойко.

Фото предоставлено Юрием Климчуком (Украина).

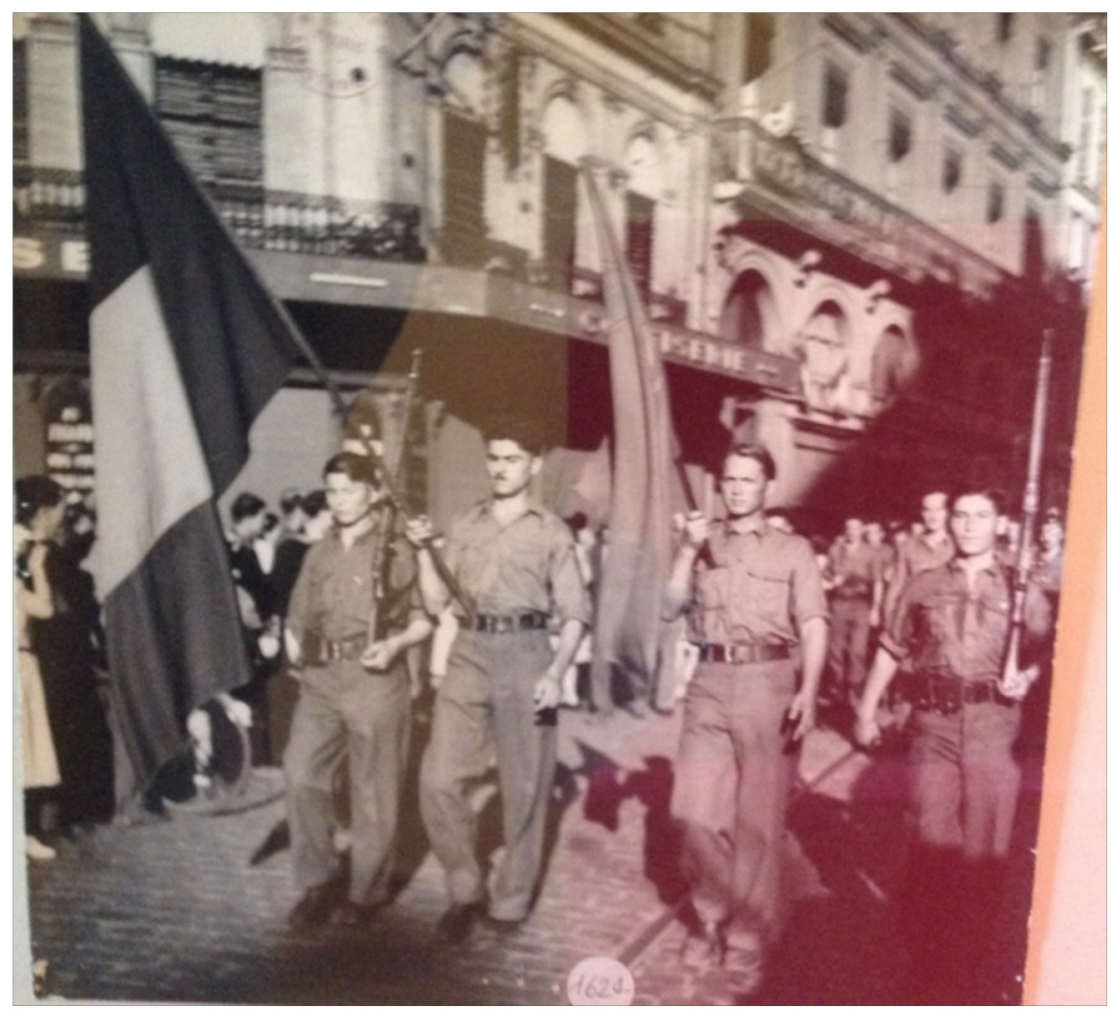

Puc. 7. Парад освобождения Тулузы от немецких захватчиков. Musée départemental de la Resistance (Toulouse). 


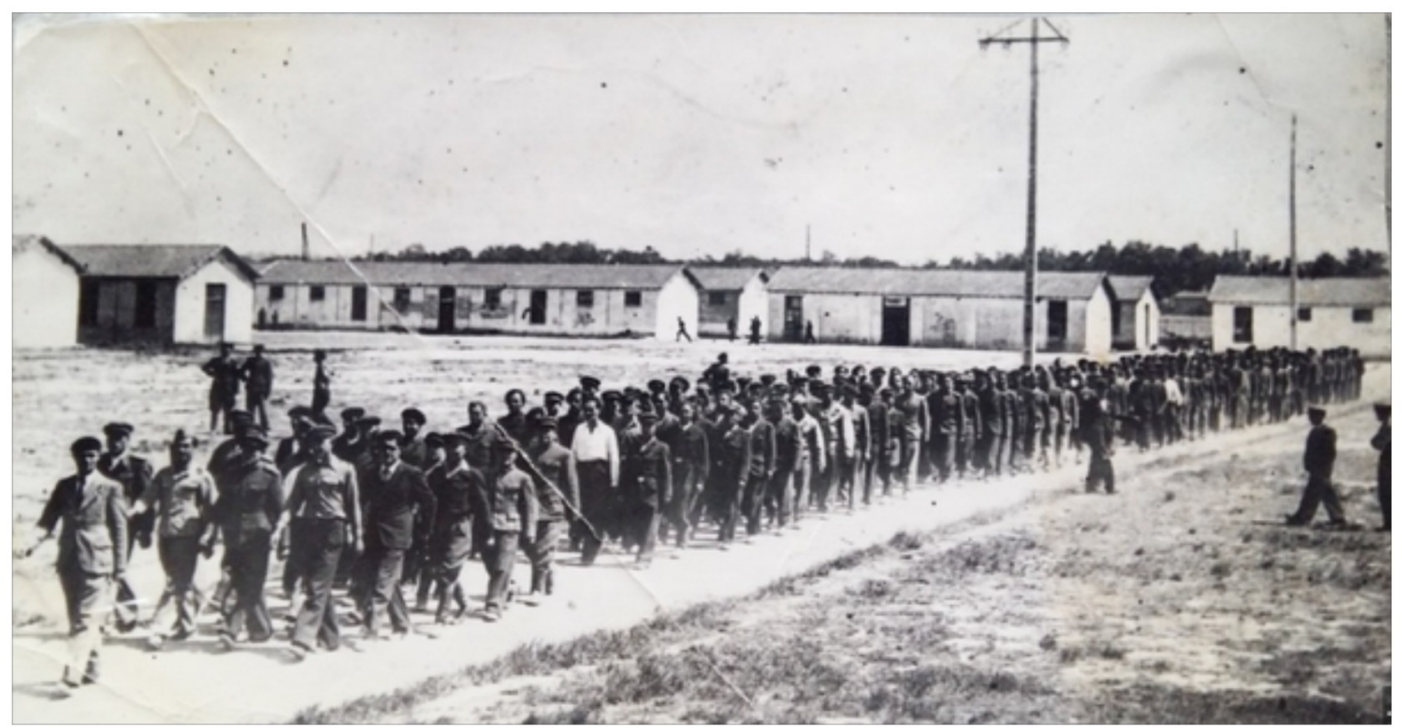

Puc. 8. Лагерь, где содержались советские военнопленные, освобождавшие Францию от фашистских оккупантов. Альби, Франция, 1944 г. Фото предоставлено Даулетом Жаманкуловым.

Позже коменданту лагеря, где содержалось 250 советских военнопленных, Зунуму Джаманкулову пришлось писать объяснительную. После разбирательств полиция признала неправоту местных жителей и подтвердила факт того, что советские солдаты героически сражались за освобождение Франции.

Таким образом, не все было просто даже после освобождения юга Франции от немецкофашистских захватчиков. Безусловно, в таких условиях всем хотелось вернуться на Родину, но они тогда еще не знали, что Родина встретит многих из них лесоповалом и ссыльными лагерями.

В период Второй мировой войны десятки наших соотечественников - казахов оказались на территории Италии и приняли самое активное участие в народно-освободительной антифашистской партизанской борьбе на территории этой страны. Это подтверждают сохранившиеся свидетельства участников событий и архивные документы.

Однако тема участия казахов в движении Сопротивления на территории Италии до сих пор остается малоизученной. Не все имена героев восстановлены и известны, их подвиги до сих пор не стали достоянием и гордостью благодарных потомков.

Так как же казахи и казахстанцы попали в далекую Италию? Итак, после жестокого подавления восстания в Риме и центральных районах Италии, осенью 1943 г. страна распалась на два воюющих лагеря. На севере начало мощно разворачиваться движение Сопротивления, воевавшее как с режимом дуче - Муссолини и его чернорубашечниками, так и с гитлеровской оккупацией. Кандидат исторических наук М.Г. Талалай о ситуации в Италии того времени пишет: «При этом вооруженный и яростный конфликт между партизанами и приверженцами дуче (их пренебрежительно назвали “республиканчиками”, repubblichini, по Республике Сало́) все более приобретал черты гражданской войны - термин, который отрицался в “левой” историографии, предпочитавшей говорить об “антифашистской народной войне” и о “партизанской войне”»"

Именно в это время, т.е. осенью 1943 г., в Италию прибыли первые крупные партии советских военнопленных и угнанных на работы; многим из них удалось бежать и влиться в движение Сопротивления (самые первые военнопленные появились еще весной 1942 г. пленники Итальянской армии на Восточном фронте). «Военные действия на территории Апеннин, с возраставшим размахом, шли весь 1944 г. и первые месяцы 1945 г. - в них в итоге участвовало около 5 тыс. выходцев из России и СССР - в рядах Сопротивления,

\footnotetext{
${ }^{43}$ Талалай М.Г. Русские участники Итальянской войны 1943-1945: партизаны, казаки, легионеры. М., 2015. C. 16 .
} 
и более 30 тыс. - коллаборационистов, воинов Русской освободительной армии («власовцев»), Казачьего стана («красновцев») и Восточных легионов. Однако многие из посланных сюда коллаборационистов саботировали свои обязанности и даже дезертировали из вермахта или уходили к партизанам» ${ }^{44}$.

Идея использования тюрков СССР в борьбе против Советского Союза должна была с готовностью быть принята немецким верховным командованием, чей подход к таким проблемам был вполне прагматичен ${ }^{45}$. Вермахт был уверен в следующих четырех позициях: во-первых, в силе влияния пропаганды тюркских военнопленных на другие советские отряды тюркского происхождения; во-вторых, в их политическом потенциале в деле минимизации вражеского сопротивления; в-третьих, в достижении быстрого умиротворения оккупированной территории; в-четвертых, в возможности формирования для себя союзников среди этого населения.

Подавляющее большинство тюркских добровольцев было завербовано из числа советских военнопленных, захваченных немцами. 162-й пехотной дивизии под командованием Генерала Оскара фон Нидермайера (General Oscar von Niedermayer), известного немецкого специалиста по ближневосточным делам, была дана задача по организации их в боевые батальоны. Эта деятельность была осуществлена Группой армий «Юг», которая в основном была сконцентрирована в центральной части Украины. В совершенно секретной докладной записке Розенберга (Rosenberg) сообщается о его обсуждении с Гитлером 14.12.1941 г. (указывается эта дата) вопроса о завершении частичной «тюркизации» этих соединений и оценки данного опыта как успешного ${ }^{46}$.

Так, в Италию осенью 1943 г. была переправлена 162-я (тюркская) пехотная дивизия (нем. 162 (Turk) Infanterie-Division), сформированная 23.05.1943 г. ${ }^{47}$ Однако в монографии О.В. Романько называется другая дата - 21.05.1943 г . ${ }^{48}$ Исследователь дополняет интересной информацией данный факт: это была экспериментальная группа и называлась Turkomann-Infanterie-Division No. 162.

Дивизия была сформирована из тюркоязычных граждан СССР - пленных азербайджанцев, казахов, узбеков, туркмен и кыргызов. Однако весь офицерский состав и большинство унтер-офицеров в дивизии были гражданами Германии.

29.09.1943 г. Гитлер отдал приказ о переводе всех восточных легионов на территорию стран Западной Европы, подальше от Восточного фронта, т.к. он уже не верил в преданность легионеров. 2 октября вышел приказ немецкого генштаба за № 10570/43, в котором, в частности, указывалось на то, что штаб Туркестанского легиона переводится на юг Франции в городок Альби ${ }^{49}$.

Прибыв в Италию, дивизия вела бои против американо-британских войск в районе Римини в 1944 г., а в 1945 г. участвовала в боях за Болонью и Падую. В мае 1945 г. в конце войны дивизия сдалась британским войскам.

О масштабах движения Сопротивления в Италии со второй половины 1943 г. свидетельствуют следующие данные, приводимые Пальмиро Тольятти: всего насчитывалось 575 гарибальдийских бригад, 198 соединений организации «Джустиция э либерта», 255 автономных частей, 70 социалистических частей имени Маттеотти и 54 народные бригады ${ }^{50}$ По сведениям бывшего Генерального секретаря, ИКП Луиджи Лонго, органы итальянского

\footnotetext{
${ }^{44}$ Талалай М.Г. Русские участники Итальянской войны... С. 17.

${ }^{45}$ Fischer G. Soviet Opposition to Stalin. Harvard Univ. Press, 1952. P. 14 f.; Anders W. Hitler's Defeat in Russia Chicago, 1953. P. 176.

${ }^{46}$ Trial of Major War Criminals before the International Military Tribunals. Nuremberg, 1948. Vol. XXVII, Trial Doc. 1517, p. 272.

47 162-я (тюркская) пехотная дивизия (вермахт). URL: https://ru.wikipedia.org/wiki/162-я_(тюркская)_пехотная дивизия_(вермахт)

${ }^{48}$ Романько О.В. Мусульманские легионы во Второй мировой войне. М., 2004. С. 208.

${ }^{49}$ Казахи во Второй мировой войне... С. 153.

${ }^{50}$ Тольятти П. Итальянская коммунистическая партия. М., 1959. С. 75.
} 
правительства в мае 1945 г. зарегистрировали 350425 участников партизанского движения в Италии ${ }^{51}$.

Свидетельствуя об активном участии советских людей в антифашистской борьбе на территории Италии, видный историк итальянского движения Сопротивления Роберто Батталья писал: «Без всяких колебаний присоединялись к партизанскому движению бывшие военнопленные Советской армии, начиная от тех неизвестных солдат, которые подали сигнал к восстанию и сами погибли в бою в районе Санта Мария Капуа Ветере, до более известных людей, оставивших по себе долгую память. Один советский майор в провинции Кунео взял на себя командование отрядом бойцов, входивших в бригаду «Паоло Браччини» ${ }^{52}$.

Документы и свидетельства о деятельности казахстанцев, воевавших в итальянской партизанской бригаде «Гуидо Баскалья», хранятся в Центральном государственном архиве Республики Казахстан ${ }^{53}$.

Так, Альпеисов Такиш родился в 1909 г. в ауле № 5 Нуринского района Карагандинской области. До войны работал трактористом. Был призван в ряды Красной армии 19.08.1941 г., и после прохождения службы в 19 стрелковом полку в Алма-Ате, а затем в Гурьеве, был в марте 1942 г. направлен на фронт. В августе 1942 г. в боях под Харьковом он был взят в плен, отправлен в Польшу, затем в лагерь «Нойгаммер» на территории Германии, а в середине 1943 г. - в Италию.

В начале 1944 г. Такиш Альпеисов бежал из плена вместе с Кенжегали Торекешевым и Жанбаем Жакеновым. После двухнедельных скитаний в горах они были замечены итальянскими партизанами и оказались в расположении партизанского соединения «Гуидо Баскальо».

Такиш Альпеисов и его товарищи принимали активное участие в диверсионных акциях против немецких и итальянских фашистов, нападали на вражеские посты и казармы, участвовали в налетах на железнодорожные мосты и тоннели. В конце 1944 г. в числе других советских воинов, боровшихся в Италии с фашизмом, при помощи советской военной миссии он был отправлен через Суэц - Тегеран - Баку на Родину ${ }^{54}$.

В ОБД «Мемориал» присутствуют только сухие данные:

ID: $85538935^{55}$

Фамилия: Альпеисов

Имя: Тукеш

Дата рождения/Возраст: .1909

Воинское звание: сержант

Причина выбытия: попал в плен (освобожден)

Название источника донесения: ЦАМО

Номер фонда источника информации: ПП г. Бендер-Шах

Номер описи источника информации: 442362

Номер дела источника информации: 7

Следующим этапом нашей работы стало выявление документов в итальянских архивах Istituto storico della Resistenza in Toscana ${ }^{56}$ и Istituto Storico Parri Emilia Romagna (Институт истории и памяти 1900-х гг. Парри Эмилия-Романья) ${ }^{57}$ об участии казахов в итальянском движении Сопротивления.

\footnotetext{
51 Лонго Л. Народ Италии в борьбе. М., 1951. С. 16.

${ }^{52}$ Батталья Р. История итальянского движения Сопротивления. М., 1954. С. 377.

${ }^{53}$ ЦГА РК. Ф. 1660. Оп. З. Д. 4. Л. 1-28.

${ }^{54}$ Там же. Д. 6. Л. 2-4.

${ }^{55}$ Обобщенный банк данных «Мемориал» [Электронный ресурс]. URL: https://obd-memorial.ru/html/info.htm? id=85538935 (дата обращения: 12.03.21).

${ }^{56}$ Istituto storico della Resistenza in Toscana (Firenza) [Электронный реусрc]. URL: http:// www.istoresistenzatoscana.it/ (дата обращения: 12.03.21).

${ }^{57}$ Istituto Storico Parri Emilia Romagna (Bologna) [Электронный реусрс]. URL: http://www.istitutoparri.eu/en/ (дата обращения: 12.03.21).
} 
В фонде Partigiani e patrioti («Партизаны и патриоты») Istituto storico della Resistenza in Toscana был обнаружен список из 30 казахов, которые участвовали в антифашистской борьбе итальянского народа с нацизмом и фашизмом.

Исследовательская группа выполнила поисковые сопоставительно-аналитические работы (в ходе командировок в Италию и Россию), связанные с изучением данных об участии казахов в итальянском движении Сопротивления. Работа затруднялась тем, что имена и фамилии были неправильно написаны как на итальянском, так и зачастую на русском языках. Поэтому мы публикуем документы из ОБД «Мемориал» и «Банка данных погибших и пропавших без вести в период Великой Отечественной войны военнослужащих, призванных с территории Казахстана» ${ }^{58}$, найденные нами.

Благодаря сопоставительно-аналитической обработке в поиске было идентифицировано 127 казахов, среди которых точно установлен 61 участник движения антифашистского и антинацистского сопротивления в Италии, которых репатриировали из разных портов Италии (например, Бари) в Одессу (СССР) или пересылочный пункт в Бендер-Шахе (Иран). Необходимо продолжить дальнейшие поиски в казахстанских, российских и итальянских архивах.

Полностью вся информация представлена в первом и втором томах издания «Казахи во Второй мировой войне: документы из зарубежных архивов», опубликованных в 2018 и 2020 г. Таким образом, в нашем исследовании мы дополняем и расширяем эти документы, благодаря материалам, извлеченным из зарубежных и личных архивов, что считаем очень важным делом как для развития исторической науки Республики Казахстан, восстановления исторической справедливости и правды, так и для укрепления национальной идеи и военнопатриотического воспитания нашей молодежи.

\section{Лumepamypa}

Абишев Г.А. Казахстан в защите социалистического Отечества. Алма-Ата: Казахстан, 1969. 359 c.

Антонов С. Казахские партизаны во Франции: как казахи воевали в Европейском Движении Сопротивления, 16.06.2016 // Vox Populi. URL: https:/voxpopuli.kz/kazahskiepartizany-vo-francii-kak-kazahi-voevali-v-evropeyskom-dvizhenii-soprotivleniya-13124/ (дата обращения: 18.03.2021).

Аяган Б.Г. Красные и черные (материалы Гуверовского архива). Алматы: Казак энциклопедиясы, 2005. 240 с.

Батталья P. История итальянского движения Сопротивления. М.: Издательство иностранной литературы, 1954. 656 с.

Бекенов С. Қазақ тұтқыны. Алматы: Қазақ энциклопедиясының, 2007. 256 б.

Белан П.С. Казахстанцы в боях за Ленинград. Алма-Ата: Наука, 1973. 242 с.

Габдуллина А.Ж. «В тени памяти» или судьба бывшего военнопленного Мажита Бектанова // Социо-гуманитарные науки в цифровом мире: сб. мат-лов Междунар. кругл. стола. Алматы: КазНТУ им. К.И. Сатпаева, 2018. С. 33-35.

Долголюк А.А., Маркдорф Н.М. Иностранные военнопленные и интернированные в Сибири (1943-1950). М.: Кучково поле, Императорское русское историческое общество, 2016. 544 с.

Дугас И.А., Черон Ф.Я. Вычеркнутые из памяти. Советские военнопленные между Гитлером и Сталиным. Париж, 1994. 432 с.

Земсков В.Н. Возвращение советских перемещенных лиц в СССР. 1944-1952 гг. М.: Ин-т рос. истории РАН: Центр гум. иниц., 2016. 424 с.

Казак В.Н. Побратимы. Советские люди в антифашистской борьбе народов балканских стран 1941-1945. М.: Мысль, 1975. 176 с.

\footnotetext{
${ }^{58}$ Қазақстан Республикасы Қорғаныс министрлігі [Электронный ресурс]. URL: https://mod.gov.kz/memorial/ pages/a/a1.html (дата обращения: 12.03.21).
} 
Казахи во Второй мировой войне: документы из зарубежных архивов: сб. док-тов. Т. 1 / сост. Г.М. Мендикулова, Е.А. Надежук, А.А. Акатаева, А.Ж. Габдуллина, Г. Байтасова. Алматы: Satbayev University, 2018. 383 с.

Казахи во Второй мировой войне: документы из зарубежных архивов: сб. док-тов. Т. 2 / Сост. Г.М. Мендикулова, Е.А. Надежук, А.А. Акатаева, Т.С. Тумабаев, Г. Абдигапарова. Алматы: Satbayev University, 2020. 353 с.

Канафина Ж. Туркестанцы во Второй мировой войне: из плена в Сопротивление. 13.05.2016 // Informburo. URL: http://informburo.kz/stati/turkestancy-vo-vtoroy-mirovoy-voyneiz-plena-v-soprotivlenie.html (дата обращения: 24.03.21).

Қара А. Түркістан легионың ақиқаты: свастика мен қызыл жұлдыз арасындағы жанталас. Түркістан, 2011.

Козыбаев М.К. Казахстан - арсенал фронта. Алма-Ата: Казахстан, 1970. 475 с.

Котек Ж., Ригуло П. Век лагерей. Лишение свободы, концентрация, уничтожение. Сто лет злодеяний. М., 2003. 687 с.

Лонго Л. Народ Италии в борьбе / пер. с итал. М.: Иностранная литература, 1951. 395 с.

Маляр И.И. Участие казахстанцев в антифашистской народно-освободительной борьбе в странах Европы (1942-1945 гг.): дис. ... канд. ист. наук. Алма-Ата, 1968.

Маляр И.И. Участие казахстанцев в европейском Движении сопротивления // Петров И.И. Всегда начеку. Алма-Ата, 1971. С. 160-168.

Мендикулова Г.М. Вторая мировая война: сражения отгремели, проблемы остались. 01.09.2016 // Интернет-газета Zona.kz. URL: https://zonakz.net/2016/09/01/vtoraja-mirovajavojjna-srazhenija-otgremeli-problemy-ostalis/ (дата обращения: 24.03.2021).

Мендикулова Г.М. Исторические судьбы казахской диаспоры. Происхождение и развитие. Алматы: Гылым, 1997. 261 с.

Мендикулова Г.М. О компаративистике и достоверности архивных и оцифрованных документов об участии казахов во Второй мировой войне // Социо-гуманитарные науки в цифровом мире: сб. мат-лов Междунар. кругл. стола. Алматы: КазНТУ им. К.И. Сатпаева. 2018. С. 19-23.

Мендикулова Г.М. Памятники казахским воинам на французской земле // Сборник материалов международной научно-практической конференции «Батыры Великой степи», 19.10.2018. Астана, 2018. С. 174-179.

Мендикулова Г.М., Надежук Е.А., Акатаева А.А., Оспанов Т.Т., Тумабаев Т.С. Участие казахов в Движении Сопротивления в Бельгии (новые архивные документы) // Вестник КарГУ. 2020. № 3. С. 172-182.

Мендикулова Г.М., Надежук Е.А., Габдуллина А.Ж., Акатаева А.А, Тумабаев Т.С. Военнопленные казахи в лагерях Норвегии и Финляндии в годы Второй мировой войны // Вопросы истории. 2019. № 10. С. 169-178.

Паникар M.M. Советские военнопленные в Норвегии в годы Второй мировой войны. Архангельск: Агентство СІР Архангельской ОНБ, 2010. 152 с.

Полян П.М. Жертвы двух диктатур: жизнь, унижения и смерть советских военнопленных и остарбайтеров на чужбине и на родине. М., 2002. 978 с.

Романько О.В. Мусульманские легионы во Второй мировой войне. М.: АСТ; Транзиткнига, 2004. 320 с.

Садыкова Б.И. История Туркестанского легиона в документах. Алматы: Кайнар, 2002. 247 c.

Семиряга М.И. Коллаборационизм. Природа, типология и проявления в годы Второй мировой войны. М.: Российская политическая энциклопедия (РОССПЭН), 2000. 863 с.

Смайыл M. Кассе Себеро - стало известно настоящее имя героя-казаха. 01.10.2018 // Tengrinews. URL: https://tengrinews.kz/story/kasse-sebero-stalo-izvestno-nastoyaschee-imyageroya-kazaha-354674/ (дата обращения: 24.03.2021).

Советские люди в освободительной борьбе югославского народа. 1941-1945 гг.: Воспоминания, документы и материалы / предисл. В. Быстрова. М.: Наука, 1973. 207 с. 
Сыздыкова А., Тепсаев Б. В зарубежных архивах нашли информацию о казахстанцах, участвовавших в ВОВ. 06.05.2019 // Телеканал «Хабар 24». URL: https://24.kz/ru/news/social/ item/313207-v-zarubezhnykh-arkhivakh-nashli-informatsiyu-o-kazakhstantsakh-uchastvovavshikhv-vov (дата обращения: 18.03.2021).

Талалай М.Г. Русские участники Итальянской войны 1943-1945: партизаны, казаки, легионеры. М.: Старая Басманная, 2015. 408 с.

Тольятти П. Итальянская коммунистическая партия. М.: Государственное издательство иностранной литературы, 1951. 159 с.

Філінюк А., Мендікулова Г., Клімчук Ю. Участь представників України та Казахстану у французькому русі опору періоду Другої світової війни: транснаціональний аспект // Вісник Кам’янець-Подільського національного університету імені Івана Огієнка. Історичні науки. 2018. Вип. 11. С. 532-550.

Шакибаев С. Падение «Большого Туркестана». Алма-Ата: Жазушы, 1973. 288 с.

Anders W. Hitler’s Defeat in Russia Chicago: Regnery, 1953. 324 p.

Bertaux P. La libération de Toulouse et de sa région - Haute-Garonne, Ariège, Gers, Hautes-Pyrénées, Lot, Lot-et-Garonne, Tarn, Tarn-et-Garonne. Paris: Hachette, 1973. 270 p.(La Libération de la France).

Fischer G. Soviet Opposition to Stalin. Harvard Univ. Press, 1952. P. 14 f.

Mendikulova G., Nadezhuk E. Kazakh-Russian roots of Alla Ilchun (Yelshin), Combated with fascism, the future Muse of Christian Dior (December 10, 1926 - March 6, 1989) // Вестник КазНУ им. Аль-Фараби. Сер. историческая. Окт. 2019. № 3 (94). С. 101-107.

Mendikulova G., Nadezhuk E., Akatayeva A. New Documents on Kazakhs in the European Resistance Movements during World War II // Journal of Modern Turkish History. Spring 2019. Vol. 15. Iss. 29. P. 205-226.

Mendikulova G.M. New documents about Kazakhs (called Mongols) in France in 1944-1945 // Евразийская цивилизация: история и современность: сб. мат-лов Междунар. науч.-практ. конф. Улаанбаатар, 2018. С. 69-72.

Mendikulova G.M., Nadezhuk E.A. The Participation of Kazakhs in the Resistance Movement in France and Italy during the World War II: Problem Posing // Вестник КазНУ. Сер. историческая. 2018. № 3 (90). C. 9-15.

Soleim M.N. Sovjetiske Krigsfanger i Norge 1941-1945; Antall, Organisering og repatriering. Oslo: Spartacus Forlag, 2009. 464 s.

Streim A. Die Behandlung sowijetischer Kriegsgefangenenlager im "Fall Barbarossa”. Heidelberg; Karlsruhe: C.F. Müller Juristischer Verl., 1981. 442 S.

Streit Ch. Keine Kameraden: Die Wehrmacht und die sowjetischen Kriegsgefangenen, 19411945. Bonn: Verl. J.H.W. Dietz, 1997. 448 S.

\section{References}

Abishev, G.A. (1969). Kazakhstan v zashchite sotsialisticheskogo Otechestva [Kazakhstan in defense of the socialist Fatherland]. Alma-Ata, Izdatelystvo Kazakhstan. 359 p.

Anders, W. (1953). Hitler's Defeat in Russia Chicago: Regnery. 324 p.

Antonov, S. (2016). Kazakhskie partizany vo Frantsii: kak kazakhi voevali v Yevropeyskom Dvizhenii Soprotivleniya. 16.06.2016. [Kazakh partisans in France: how Kazakhs fought in the European Resistance Movemen]. In Vox Populi. URL: http://www.voxpopuli.kz/history/kazahskiepartizany-vo-francii-kak-kazahi-voevali-v-evropeyskom-dvizhenii-soprotivleniya-13124.html

Ayagan, B.G. (2005). Krasnye i chernye (materialy Guverovskogo arkhiva) [Red and black (materials from the Hoover Archives)]. Almaty, Kazak entsiklopediyasy. 240 p.

Battalyya, R. (1954). Istoriya italyyanskogo dvizheniya Soprotivleniya [History of the Italian Resistance Movement]. Moscow, Izdatelstvo inostrannoy literatury. 656 p.

Bekenov, S. Kazak tutkyny. Almaty, Kazakstan entsiklopediyasynyn, 2007. 256 b.

Belan, P.S. (1973). Kazakhstantsy v boyakh za Leningrad [Kazakhs in battles for Leningrad]. Alma-Ata, Nauka. 242 p. 
Bertaux P. (1973). La libération de Toulouse et de sa région - Haute-Garonne, Ariège, Gers, Hautes-Pyrénées, Lot, Lot-et-Garonne, Tarn, Tarn-et-Garonne. Paris, Hachette. 270 p. (La Libération de la France).

Dolgolyuk, A.A., Markdorf, N.M. (2016). Inostrannye voennoplennye i internirovannye v Sibiri (1943-1950) [Foreign prisoners of war and internees in Siberia (1943-1950)]. Moscow: Kuchkovo pole, Imperatorskoe russkoe istoricheskoe obshchestvo. 544 p.

Dugas, I.A., Cheron, F.Ya. (1994). Vycherknutye iz pamyati. Sovetskie voennoplennye mezhdu Gitlerom i Stalinym [Erased from memory. Soviet prisoners of war between Hitler and Stalin]. Parizh. 432 p.

Fischer, G. (1952). Soviet Opposition to Stalin. Harvard Univ. Press. 14 f.

Gabdullina, A.Zh. (2018). "V teni pamyati” ili sudyba byvshego voennoplennogo Mazhita Bektanova ["In the shadow of memory"or the fate of the former prisoner of war Mazhit Bektanov]. In Sotsio-gumanitarnye nauki v tsifrovom mire. Sbornik materialov Mezhdunarodnogo kruglogo stola. Almaty: KazNTU imeni K.I. Satpaeva, pp. 33-35.

Kanafina, Zh. (2016). Turkestantsy vo Vtoroy mirovoy voyne: iz plena v Soprotivlenie 13.05.2016 [Turkestanis in World War II: From Captivity to the Resistance]. Ingormburo. URL: https://informburo.kz/stati/turkestancy-vo-vtoroy-mirovoy-voyne-iz-plena-v-soprotivlenie.html (date of access 24.03.21).

Kazak, V.N. (1975). Pobratimy. Sovetskie lyudi v antifashistskoy borbe narodov balkanskikh stran 1941-1945 [Twin brothers. Soviet people in the anti-fascist struggle of the peoples of the Balkan countries 1941-1945]. Moscow, Mysly. 176 p.

Kotek, Zh., Rigulo, P. (2003). Vek lagerey. Lishenie svobody, kontsentratsiya, unichtozhenie. Sto let zlodeyaniy [Age of camps. Deprivation of freedom, concentration, destruction. One hundred years of atrocities].Moscow. 687p.

Kozybaev, M.K. (1970). Kazakhstan - arsenal fronta [Kazakhstan - the arsenal of the front]. Alma-Ata, Kazakhstan. 475 p.

Longo, L. (1951). Narod Italii v borbe [The people of Italy in the struggle]. Moscow. Inostrannaya literatura. $395 \mathrm{p}$.

Malyar, I.I. (1968). Uchastie kazakhstantsev v antifashistskoy narodno-osvoboditelynoy borybe $v$ stranakh Yevropy (1942-1945 gg.) [Participation of Kazakhstanis in the anti-fascist people's liberation struggle in European countries (1942-1945)], Cand. hist. sci. diss. abstract. Alma-Ata.

Malyar, I.I. (1971). Uchastie kazakhstantsev v evropeiskom dvizhenii soprotivleniya. In Petrov, I.I. Vsegda nacheku. Alma-Ata, pp. 160-168.

Mendikulova, G.M. (2018). New documents about Kazakhs (called Mongols) in France in 1944-1945. In Evraziyskaya civilizatsiya: istoriya i sovremennost. Ulaanbaatar, pp. 69-72.

Mendikulova, G.M., Nadezhuk, E.A. (2018). The Participation of Kazakhs in the Resistance Movement in France and Italy during the World War II: Problem Posing. In Vestnik KazNU imeni Al-Farabi. Seriya istoricheskaya. No. 3 (90), pp. 9-15.

Mendikulova, G., Nadezhuk, E. (2019). Kazakh-Russian roots of Alla Ilchun (Yelshin), Combated with fascism, the future Muse of Christian Dior (December 10, 1926 - March 6, 1989). In Vestnik KazNU imeni Al-Farabi. Seriya istoricheskaya. No. 3 (94), pp. 101-107.

Mendikulova, G., Nadezhuk, E., Akatayeva, A. (2019). New Documents on Kazakhs in the European Resistance Movements during World War II. In Journal of Modern Turkish History. Vol. 15. Iss. 29, pp. 205-226.

Mendikulova, G.M., Nadezhuk, Ye.A., Akataeva, A.A., Gabdullina, A.Zh., Baytasova, G. (Eds.). (2018). Kazakhi vo Vtoroy Mirovoy voyne: dokumenty iz zarubezhnykh arkhivov: T. 1. Sbornik dokumentov [Kazakhs in the Second World War: documents from foreign archives: Vol. 1. Collection of documents]. Almaty, Satbayev University. 383 p.

Mendikulova, G.M., Nadezhuk, Ye.A.,. Akataeva, A.A, Tumabaev, T.S., Abdigaparova, G. (Eds.). (2020). Kazakhi vo Vtoroy Mirovoy voyne: dokumenty iz zarubezhnykh arkhivov. T. 1. Sb. dokumentov [Kazakhs in the Second World War: documents from foreign archives: Vol. 1. Collection of documents]. Almaty, Satbayev University. 353 p. 
Mendikulova, G.M. (1997). Istoricheskie sudby kazakhskoy diaspory. Proiskhozhdenie i razvitie [Historical destinies of the Kazakh diaspora. Origin and development]. Almaty, Gylym. 261 p.

Mendikulova, G.M. (2016). Vtoraya mirovaya voyna: srazheniya otgremeli, problemy ostalis [World War II: battles died down, problems remained 01.09.2016.]. In Internet-gazeta Zona kz. URL: $\quad$ https://zonakz.net/2016/09/01/vtoraja-mirovaja-vojjna-srazhenija-otgremeli-problemyostalis/ (date of access 24.03.21).

Mendikulova, G.M. (2018). O komparativistike i dostovernosti arkhivnykh i otsifrovannykh dokumentov ob uchastii kazakhov vo Vtoroy mirovoy voyne [On comparative studies and the reliability of archival and digitized documents on the participation of Kazakhs in World War II]. In Sotsio-gumanitarnye nauki v tsifrovom mire. Sbornik materialov Mezhdunarodnogo kruglogo stola. Almaty, KazNTU imeni K.I. Satpaeva, pp. 19-23.

Mendikulova, G.M. (2018). Pamyatniki kazakhskim voinam na frantsuzskoy zemle. 19.10.2018 [Monuments to Kazakh soldiers on French soil]. In Sbornik materialov mezhdunarodnoy nauchnoprakticheskoy konferentsii "Batyry Velikoy stepi”. Astana, pp. 174-179.

Mendikulova, G.M., Nadezhuk, Ye.A., Akataeva, A.A, Ospanov, T.T., Tumabaev, T.S. (2020). Uchastie kazakhov v Dvizhenii Soprotivleniya v Belygii (novye arkhivnye dokumenty) [Participation of Kazakhs in the Resistance Movement in Belogiya (new archival documents)]. In Vestnik KarGU. No. 3, pp. 172-182.

Mendikulova, G.M., Nadezhuk, Ye.A., Gabdullina, A.Zh., Akataeva, A.A., Tumabaev, T.S. (2019). Voennoplennye Kazakhi v lageryakh Norvegii i Finlyandii v gody Vtoroy Mirovoy voyny [The Kazakhs in military captivity in Norway and Finland in World War II]. In Voprosy istorii. No. 10, pp. 169-178.

Panikar, M.M. (2010). Sovetskie voennoplennye $v$ Norvegii v gody Vtoroy mirovoy voyny [Soviet prisoners of war in Norway during World War II]. Arkhangelysk, Agentstvo SIP Arkhangelyskoy ONB. 152 p.

Polyan, P.M. (2002). Zhertvy dvukh diktatur: zhizny, unizheniya i smerty sovetskikh voennoplennykh i ostarbayterov na chuzhbine i na rodine [Victims of two dictatorships: life, humiliation and death of Soviet prisoners of war and Ostarbeiters in a foreign land and at home]. Moscow. $978 \mathrm{p}$.

Qara, A. Türkistan legionyn aqiqaty: svastika men qyzyl zhūldyz arasyndağy zhantalas. Türkistan, 2011.

Romanko, O.V. (2004). Musulymanskie legiony vo Vtoroy mirovoy voyne [Muslim legions in World War II]. Moscow, AST; Tranzitkniga. 320 p.

Sadykova, B.I. (2002). Istoriya Turkestanskogo legiona $v$ dokumentakh [History of the Turkestan Legion in documents]. Almaty, Kaynar. 247 p.

Semiryaga, M.I. (2000). Kollaboratsionizm. Priroda, tipologiya i proyavleniya $v$ gody Vtoroy mirovoy voyny [Collaboration. Nature, typology and manifestations during the Second World War]. Moscow, Rossiyskaya politicheskaya entsiklopediya (ROSSPEN). 863 p.

Shakibaev, S. (1973). Padenie "Bolshogo Turkestana” [The fall of Bolusny Turkestan]. AlmaAta, Zhazushy. 288 p.

Smayyl, M. (2018). Kasse Sebero - stalo izvestno nastoyashchee imya geroya-kazakha 01.10.2018. [Cashier Severo - the real name of the Kazakh hero became known. 01.10.2018]. In Tengrinews. URL: https://tengrinews.kz/story/kasse-sebero-stalo-izvestno-nastoyaschee-imyageroya-kazaha-354674/ (date of access 24.03.21).

Soleim, M.N. (2009). Sovjetiske Krigsfanger i Norge 1941-1945; Antall, Organisering og repatriering. Oslo, Spartacus Forlag. $464 \mathrm{s.}$

(1973). Sovetskie lyudi v osvoboditelynoy borbe yugoslavskogo naroda. 1941-1945 gg.: Vospominaniya, dokumenty i materialy [Soviet people in the liberation struggle of the Yugoslav people. 1941-1945: Memories, Documents and Materials] / Predisl. V. Bystrova. Moscow, Nauka. 207 p.

Streim, A. (1981). Die Behandlung sowijetischer Kriegsgefangenenlager im "Fall Barbarossa". Heidelberg; Karlsruhe: C.F. Müller Juristischer Verl. 442 S. 
Streit, Ch. (1997). Keine Kameraden: Die Wehrmacht und die sowjetischen Kriegsgefangenen, 1941-1945. Bonn: Verl. J.H.W. Dietz. 448 S.

Syzdykova, A., Tepsaev, B. (2019). V zarubezhnykh arkhivakh nashli informatsiyu o kazakhstantsakh, uchastvovavshikh $v$ VOV. 06.05.2019 [Information about Kazakhstanis who participated in the Second World War was found in foreign archives]. In Khabar. URL: https://24.kz/ru/ news/social/item/313207-v-zarubezhnykh-arkhivakh-nashli-informatsiyu-o-kazakhstantsakhuchastvovavshikh-v-vov (date of access 24.03.21).

Talalay, M.G. (2015). Russkie uchastniki Italyyanskoy voyny 1943-1945: partizany, kazaki, legionery [Russian participants in the Italian War 1943-1945: partisans, Cossacks, legionnaires]. Moscow, Staraya Basmannaya. 408 p.

Tolyyatti, P. (1951). Italyyanskaya kommunisticheskaya partiya [Italian Communist Party]. Moscow, Gosudarstvennoe izdatelystvo inostrannoy literatury. 1951.

Zemskov, V.N. (2016). Vozvrashchenie sovetskikh peremeshchennykh lits v SSSR. 1944$1952 \mathrm{gg}$. [Return of Soviet displaced persons to the USSR. 1944-1952]. Moscow, Institut rossiyskoy istorii RAN, Tsentr gumanitarnykh initsiativ. 424 p.

Статья поступила в редакцию 14.05.2021 г. 